Hungry Dreams 
Food Systems and Agrarian Change

Edited by Frederick H. Buttel, Billie R. DeWalt, and Per Pinstrup-Andersen

A complete list of titles in the series appears at the end of this book. 


\section{HUNGRY DREAMS}

The Failure of Food Policy

in Revolutionary Nicaragua,

I979-I990

Brizio N. Biondi-Morra

Cornell University Press

ITHACA AND LONDON 
Copyright (C) I 993 by Cornell University

All rights reserved. Except for brief quotations in a review, this book, or parts thereof, must not be reproduced in any form without permission in writing from the publisher. For information, address Cornell University Press, Sage House, 5 I 2 East State Street, Ithaca, New York I 4850.

First published I993 by Cornell University Press.

Library of Congress Cataloging-in-Publication Data

Biondi-Morra, Brizio N.

Hungry dreams : the failure of food policy in revolutionary

Nicaragua, 1979-1990 / Brizio N. Biondi-Morra.

p. cm. - (Food systems and agrarian change)

Includes bibliographical references and index.

ISBN 0-80 1 4-2663-4

I. Food supply-Government policy-Nicaragua. 2. Agriculture and state-Nicaragua. I. Title. II. Series.

$\mathrm{HD}_{901} \mathrm{I}_{4} \mathrm{~N}_{52} \mathrm{~B}_{5} 6 \quad 1993$

$363.8^{\prime} 097285-\mathrm{dc} 20$

$92-56782$

Printed in the United States of America

The paper in this book meets the minimum requirements of the American National Standard for Information Sciences-

Permanence of Paper for Printed Library Materials, ANSI Z39.48-I984. 